\title{
In Vitro Evaluation of the Multidrug Resistance Reversing Activity of Novel Imidazo[4,5-b]pyridine Derivatives
}

\author{
SELMA BOURICHI ${ }^{1}$, HOURIA MISBAHI ${ }^{1}$, YOUSSEF KANDRI RODI ${ }^{1}$, FOUAD OUAZZANI CHAHDI $^{1}$, \\ EL MOKHTAR ESSASSI ${ }^{2}$, STEFÁNIA SZABÓ ${ }^{3}$, BEATRIX SZALONTAI ${ }^{3}$, \\ MÁRIÓ GAJDÁCS ${ }^{3}$, JOSEPH MOLNÁR ${ }^{3}$ and GABRIELLA SPENGLER ${ }^{3}$ \\ ${ }^{1}$ Laboratory of Applied Organic Chemistry, Faculty of Science and Technology, \\ Sidi Mohamed Ben Abdellah University, Fez, Morocco; \\ ${ }^{2}$ Laboratory of Heterocyclic Organic Chemistry URAC21, Faculty of Sciences, \\ University of Mohamed V, Rabat, Morocco; \\ ${ }^{3}$ Department of Medical Microbiology and Immunobiology, \\ Faculty of Medicine, University of Szeged, Szeged, Hungary
}

\begin{abstract}
Background/Aim: Malignant diseases present a significant public health burden worldwide and their treatment is further complicated by the phenomenon of multidrug resistance. Derivatives of imidazopyridine exhibit several remarkable pharmacological activities and they could reverse the multidrug resistance of cancer cells due to overexpressing P-glycoprotein. Materials and Methods: A series of novel imidazo[4,5-b]pyridine derivatives were synthesized and their biological activities were evaluated in vitro using parental (PAR) and multidrug resistant (MDR; ABCB1-overexpressing) mouse T-lymphoma cells. The cytotoxic activity and selectivity of the tested compounds were assessed by the thiazolyl blue tetrazolium bromide (MTT) assay, the ABCB1 modulating activity was measured by rhodamine 123 accumulation assay using flow cytometry. Results: Six compounds $(\boldsymbol{b}, \boldsymbol{c}, \boldsymbol{d}, \boldsymbol{f}, \boldsymbol{h}$ and $\boldsymbol{i})$ showed moderateto-high cytotoxic activity on the tested cell lines, while derivative $\boldsymbol{i}$ presented with promising selectivity towards the $M D R$ cell line. Derivatives $\boldsymbol{a}, \boldsymbol{d}, \boldsymbol{f}, \boldsymbol{g}$ and $\boldsymbol{i}$ were proven to be effective modulators of the ABCB1 multidrug efflux pump, with two compounds showing efflux pump modulatory activity at $2 \mu M$ concentration. Conclusion: Based on our experimental results, compounds that showed potent activity are those with a short carbon side chain; a methoxy group
\end{abstract}

Correspondence to: Houria Misbahi, Laboratory of Applied Organic Chemistry, Faculty of Science and Technology, Sidi Mohamed Ben Abdellah University, BP 2202, Fez, Morocco. Tel: +212 669421751, Fax: +212 535608214, e-mail: houriya.misbahi@usmba.ac.ma

Key Words: Imidazo[4,5-b]pyridine, MDR, ABCB1, mouse Tlymphoma. on the benzene ring; a heterocyclic (triazole) side chain and the presence of an alkylated $N$-atom at position 4 .

Malignant diseases present a significant public health burden worldwide, and even with the therapeutic armamentarium of surgical interventions, radiation therapy and chemotherapeutic treatment, these diseases still represent the second major cause of mortality in the developed world (1). The emergence of cancer cells that are resistant to structurally and functionally unrelated cytostatic drugs (this phenotype is termed multidrug resistance or MDR) further complicated the treatment of these diseases (2). A common mechanism for the reduction of chemotherapeutic efficacy is the overexpression of ATP-binding cassette (ABC) drug transporters (3).

Compounds containing the imidazo[4,5-b]pyridine moiety have been reported for various activities such as anticancer (4$6)$, antiviral (7-9) antimitotic (10), anti-inflammatory $(11,12)$ and tuberculostatic $(13,14)$. In addition, imidazo[4,5-b]pyridine may act as an antagonist of various biological receptors (15) including angiotensin-II, platelet activating factor (PAF) (16), subtype metabotropic glutamate V3 (17), AT1 receptor (18) and adenosine A2a (19). The imidazo[4,5-b]pyridine heterocyclic system is also a structural analogue of purine, whose derivatives readily interact with large biomolecules such as DNA, RNA and proteins in vivo. The structural homology with the adenine nucleus would allow imidazopyridine derivatives to be able to reverse multidrug resistance by inhibiting the activity of $\mathrm{P}$ glycoprotein (ABCB1) (20).

In the present study, a series of newly-synthesized imidazo[4,5-b]pyridine derivatives (9 compounds) were investigated regarding their cytotoxicity and their ABCB1modulating properties against parental and ABCB1overexpressing MDR mouse T-lymphoma cells in vitro. 


\section{Materials and Methods}

Compounds. The imidazo[4,5-b]pyridine derivatives tested were synthesized by alkylation (Figure 1A) and 1,3-dipolar cycloaddition (Figure 1B). Condensation of 5-bromo-2,3-diaminopyridine with 4chlorobenzaldehyde or 4-methoxybenzaldehyde in water for $48 \mathrm{~h}$ at $100^{\circ} \mathrm{C}$ in the presence of $\mathrm{I}_{2}$ resulted in Derivative 1 (21). Derivatives 2, 2', 3 were obtained by the reaction of Derivative 1 with monohalogenated reagents under phase transfer catalysis conditions, using tetra-n-butylammonium bromide (BTBA) as a catalyst, $\mathrm{K}_{2} \mathrm{CO}_{3}$ as a base and $\mathrm{N}, \mathrm{N}$-dimethylformamide as solvent (22). Derivative $\mathbf{4}$ was obtained by the condensation of azides with acetylenic compounds by 1,3-dipolar cycloaddition. Substituents of the tested compounds, reaction yields and melting points are shown in Table I. Compounds were solved in DMSO to obtain stock solutions. Afterwards, working solutions were prepared by dilution in water, the concentration of DMSO was below $1 \%$ in all the experiments.

Other chemicals used in the study as reagents were: 3-(4,5dimethylthiazol-2-yl)-2,5-diphenyltetrazolium bromide (MTT; SigmaAldrich, St Louis, MO, USA), sodium dodecyl sulphate (SDS; SigmaAldrich, St Louis, MO, USA), rhodamine 123 (R123; Sigma, St. Louis, MO, USA), verapamil (EGIS Hungarian Pharmaceutical Company, Budapest, Hungary) and dimethyl sulfoxide (DMSO; Sigma-Aldrich, St Louis, MO, USA). Stock solutions of R123 were prepared in phosphate buffered saline and verapamil was dissolved in water. All solutions were prepared on the day of the assay.

Cell lines. L5178Y mouse T-cell lymphoma cells (PAR) (ECACC Cat. No. 87111908, obtained from FDA, Silver Spring, MD, USA) were transfected with $\mathrm{pHa}$ MDR1/A retrovirus, as previously described by Cornwell et al. (23). The ABCB1-expressing cell line L5178Y (MDR) was selected by culturing the infected cells with colchicine. The L5178Y human ABCB1-transfected subline was cultured in McCoy's 5A medium (Sigma-Aldrich, St Louis, MO, USA) supplemented with $10 \%$ heat-inactivated horse serum (SigmaAldrich), $200 \mathrm{mM} \mathrm{L-glutamine} \mathrm{(Sigma-Aldrich)} \mathrm{and} \mathrm{a} \mathrm{penicillin-}$ streptomycin (Sigma-Aldrich) mixture in concentrations of $100 \mathrm{U} / 1$ and $10 \mathrm{mg} / \mathrm{l}$, respectively. The cell lines were incubated at $37^{\circ} \mathrm{C}$, in a $5 \% \mathrm{CO}_{2}, 95 \%$ air atmosphere.

Assay for cytotoxic effect. The effects of increasing concentrations of the tested imidazo[4,5-b]pyridine derivatives on cell growth were evaluated in 96-well microtiter plates. The parental (PAR) and multidrug resistant (MDR) mouse T-lymphoma cells were cultured using McCoy's 5A medium supplemented with $10 \%$ heat-inactivated horse serum. The density of the cells was adjusted to $1 \times 10^{4}$ cells per well (in $100 \mu \mathrm{l}$ of medium per well) and then added to the 96-well flat-bottomed microtiter plates containing the dilutions of the tested compounds. The culture plates were incubated at $37^{\circ} \mathrm{C}$, in a $5 \% \mathrm{CO}_{2}$, 95\% air atmosphere.

The culture plates were incubated at $37^{\circ} \mathrm{C}$ for $24 \mathrm{~h}$; at the end of the incubation period, $20 \mu \mathrm{l}$ of MTT (Sigma) solution (from a stock solution of $5 \mathrm{mg} / \mathrm{ml}$ ) were added to each well. After incubation at $37^{\circ} \mathrm{C}$ for $4 \mathrm{~h}, 100 \mu \mathrm{l}$ of sodium dodecyl sulfate (SDS) (Sigma) solution $(10 \%$ in $0.01 \mathrm{M} \mathrm{HCI})$ were added to each well and the plates were further incubated at $37^{\circ} \mathrm{C}$ overnight. Cell growth was determined by measuring the optical density (OD) at 540/630 nm with Multiscan EX ELISA reader (Thermo Labsystems, Cheshire, WA, USA) (24). Inhibition of the cell growth was determined according to the formula below:
$\mathrm{IC}_{50}=100-\left[\frac{O D \text { sample }-O D \text { medium control }}{O D \text { cell control }-O D \text { medium control }}\right] \times 100$

Rhodamine 123 accumulation assay. The following method is based on a fluorescence-based detection system which uses verapamil as reference inhibitor of the ABCB1 efflux pump (25). The parental and multidrug resistant (MDR) subline of mouse T-lymphoma cells were adjusted to a density of $2 \times 10^{6}$ cells $/ \mathrm{ml}$ and re-suspended in serum-free McCoy's 5A medium and distributed in $500 \mu \mathrm{l}$ aliquots. The tested compounds ( 1 and $10 \mu \mathrm{l}$ from a stock solution of $1 \mathrm{mM}$, respectively) were added at different concentrations (final concentrations of $2 \mu \mathrm{M}$ and $20 \mu \mathrm{M}$, respectively), and the samples were incubated for $10 \mathrm{~min}$ at room temperature. Verapamil was used as positive control at $20 \mu \mathrm{M}$ (from a $5 \mathrm{mg} / \mathrm{ml}$ stock solution) and DMSO was used as solvent control (at $2 \mathrm{~V} / \mathrm{V} \%)$. After the first incubation period, $10 \mu \mathrm{l}(5.2 \mu \mathrm{M}$ final concentration) of rhodamine 123 were added to the samples and the cells were further incubated for $20 \mathrm{~min}$ at $37^{\circ} \mathrm{C}$, washed twice with phosphate buffered saline (PBS) and re-suspended in $1 \mathrm{ml}$ PBS for analysis. The fluorescence intensity of the gated cell population was measured with a Partec CyFlow flow cytometer (Partec, Munster, Germany). The mean fluorescence intensity was calculated for the treated MDR and parental mouse T-lymphoma cells lines as compared to the untreated cells $(26,27)$. The fluorescence activity ratio (FAR) was calculated based on the following equation which relates the measured fluorescence values:

$$
\mathrm{FAR}=\frac{\mathrm{MDR} \text { treatcd } / \mathrm{MDR} \text { control }}{\text { parental treated } / \text { parental control }} ; \text { Quotient }=100 \times\left(\mathrm{FAR}_{\text {composund }} / \mathrm{FAR}_{\text {verapamil }}\right)
$$

\section{Results}

The $\mathrm{IC}_{50}$ values (thus, the cytotoxic activity) of the tested compounds on the parental subline of the mouse T-lymphoma cells can be divided into three groups: compounds with $\mathrm{IC}_{50}$ values above $100 \mu \mathrm{M}$ (a and e), compounds with $\mathrm{IC}_{50}$ values between 20-70 $\mu \mathrm{M}$ (in decreasing order: c, g, f, b, $\mathbf{d}$ and $\mathbf{h}$ ) and derivative $\mathrm{i}$, which presented with an $\mathrm{IC}_{50}$ value of $1.73 \mu \mathrm{M}$. The $\mathrm{IC}_{50}$ values of the tested compounds on the MDR mouse T-lymphoma cells can be divided in a comparable way (compounds with $\mathrm{IC}_{50}$ values above $100 \mu \mathrm{M}$ : a, e and $\mathbf{g}$; compounds with $\mathrm{IC}_{50}$ values between $10-75 \mu \mathrm{M}$ : c, b, f, $\mathbf{d}$ and $\mathbf{h}$; and derivative $\mathbf{i}$, which presented with an $\mathrm{IC}_{50}$ value of $0.20 \mu \mathrm{M}$ ) (Table II). While the majority of the compounds had no selective cytotoxicity against the efflux pump overexpressing subline of mouse lymphoma cells (with $\mathrm{IC}_{50 \mathrm{MDR}}$ values higher than $\mathrm{IC}_{50 \mathrm{PAR}}$; SI values ranging between 0.55 and 1.49), derivative $\mathbf{i}$, which was proven to be the most cytotoxic among the tested imidazo[4,5-b]pyridine derivatives $\left(\mathrm{IC}_{50 \mathrm{PAR}}=1.73 \mu \mathrm{M}, \mathrm{IC}_{50 \mathrm{MDR}}=0.20 \mu \mathrm{M}\right)$ showed potent selectivity ( $\mathrm{SI}=8.66$ ) towards the MDR cells (Table II).

Out of the 9 tested imidazo[4,5-b]pyridine derivatives, 5 compounds (a, d, f, $\mathbf{g}$ and i) presented with potent ABCB1modulating activity (the intracellular concentration of rhodamine 123 was increased) at the same concentration as verapamil $(20 \mu \mathrm{M})$, surpassing the activity of the positive control by a considerable margin (with FAR values ranging 


\section{A}

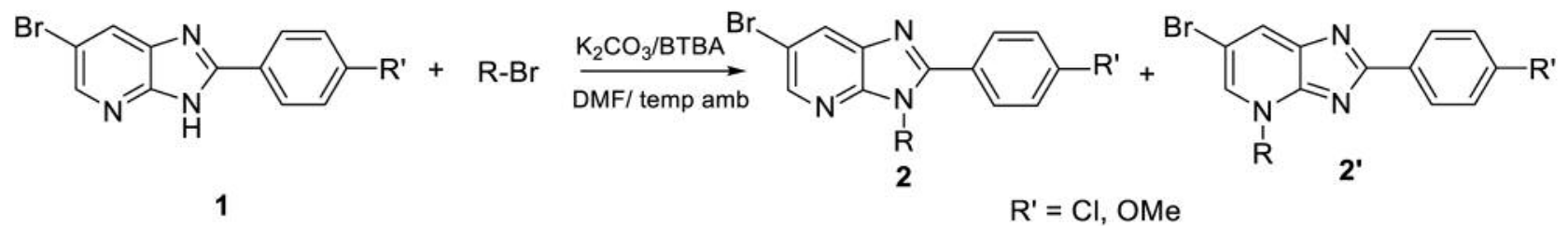

B<smiles>[R]NN=[N+]=[R]</smiles>

Figure 1. Synthesis of imidazo[4,5-b]pyridines derivatives synthesized by alkylation (A) and 1,3-dipolar cycloaddition (B).

Table I. Substituents of novel imidazo[4,5-b]pyridine derivatives.

\begin{tabular}{|c|c|c|c|c|c|}
\hline Compound & $\mathrm{R}^{\prime}$ & $\mathrm{R}$ & $\mathrm{N}^{*}$ & Reaction yield (\%) & Melting point $\left({ }^{\circ} \mathrm{C}\right)$ \\
\hline $\mathbf{a}$ & $\mathrm{Cl}$ & $\mathrm{C}_{8} \mathrm{H}_{17}$ & 3 & 66 & $96-98$ \\
\hline b & $\mathrm{Cl}$ & $\mathrm{C}_{12} \mathrm{H}_{25}$ & 3 & 36 & $80-82$ \\
\hline c & $\mathrm{Cl}$ & $\mathrm{C}_{12} \mathrm{H}_{25}$ & 4 & 36 & $78-80$ \\
\hline d & $\mathrm{OCH}_{3}$ & $\mathrm{C}_{4} \mathrm{H}_{9}$ & 3 & 72 & $92-94$ \\
\hline $\mathbf{e}$ & $\mathrm{Cl}$ & $\mathrm{C}_{8} \mathrm{H}_{17}$ & 3 & 70 & $76-78$ \\
\hline $\mathbf{f}$ & $\mathrm{Cl}$ & & 4 & 40 & $162-164$ \\
\hline g & $\mathrm{OCH}_{3}$ & & 3 & 45 & $130-132$ \\
\hline $\mathbf{h}$ & $\mathrm{Cl}$ & & 3 & 65 & $186-188$ \\
\hline i & $\mathrm{OCH}_{3}$ & $=$ & 3 & 60 & $212-214$ \\
\hline
\end{tabular}

between 19.65 and 57.55 vs. FAR $_{\text {verapamil }}=11.83$ ). Based on the results presented in Table III, the potency of the active compounds is 1.66-4.86-fold higher than verapamil's. In some cases, the efflux pump modulating activity of the compounds approaches (i, FAR quotient: $89.50 \%$ ) or surpasses (a, FAR quotient: $143.35 \%$ ) the activity of the positive control at concentrations that are ten times smaller (Table III). The case of compound $\mathbf{a}$ is especially compelling, because despite the fact that this compound was not the most potent inhibitor of the ABCB1 transporter among the tested derivatives $\left(\mathrm{FAR}_{20}\right.$ $\mu \mathrm{M}=28.09)$, it exerted its activity without any toxicity $\left(\mathrm{IC}_{50}\right.$ $>100 \mu \mathrm{M})$ on the tested cell lines.

\section{Discussion}

Compounds containing the imidazo[4,5-b]pyridine moiety represent a special group of compounds with numerous pharmacological activities $(28,29,30)$. In the present study, 
Table II. Cytotoxicity of tested compounds against parental (PAR) and multidrug-resistant (MDR) mouse lymphoma cells and selectivity indices (SI).

\begin{tabular}{lccc}
\hline & \multicolumn{3}{c}{$\mathrm{IC}_{50}(\mu \mathrm{M})$} \\
\cline { 2 - 4 } Compound & PAR (A) & MDR $(\mathrm{B})$ & $\mathrm{SI}(\mathrm{B} / \mathrm{A})$ \\
\hline a & $>100$ & $>100$ & - \\
b & $44.40 \pm 0.34$ & $57.38 \pm 0.40$ & 0.77 \\
c & $62.89 \pm 0.57$ & $73.42 \pm 0.45$ & 0.86 \\
d & $39.52 \pm 0.36$ & $47.84 \pm 0.41$ & 0.83 \\
e & $>100$ & $>100$ & - \\
f & $47.17 \pm 0.33$ & $52.88 \pm 0.63$ & 0.89 \\
g & $54.51 \pm 0.29$ & $>100$ & $<0.55$ \\
h & $21.75 \pm 0.39$ & $14.57 \pm 0.30$ & 1.49 \\
i & $1.73 \pm 0.18$ & $0.20 \pm 0.08$ & 8.66 \\
DMSO & $>2 \mathrm{~V} / \mathrm{V} \%$ & $>2 \mathrm{~V} / \mathrm{V} \%$ & - \\
\hline
\end{tabular}

DMSO: Dimethyl-sulfoxide; SD: standard deviation; SI: Selectivity Index; $\mathrm{SI}<3$ values denote slight selectivity; $3<\mathrm{SI}<6$ values indicate moderate selectivity; $\mathrm{SI}<6$ indicates strong selectivity (31).

the anticancer and efflux pump modulating activity of nine novel imidazo[4,5-b]pyridine derivatives were evaluated. Five compounds (c, $\mathbf{b}, \mathbf{f}, \mathbf{d}$ and $\mathbf{h}$ ) showed moderate cytotoxicity on the MDR cell line, while derivative i presented with potent selectivity and a very low $\mathrm{IC}_{50}$ value.

Five of these compounds exhibited significantly better MDR-reversing activity than the reference (verapamil) with a fluorescence ratio of 19.65 to 57.55 compared with 11.83 for verapamil. It should be noted that compounds that lack the potent efflux pump modulatory activity of their counterparts are those with a long carbon chain in position 3 or $4(n>4 C)$, which suggests that this moiety is not suitable for pronounced activity. Both compounds $\mathbf{h}$ and $\mathbf{i}$ are alkylated at the same position with a propargyl group, however, $\mathbf{i}$ has a methoxy and $\mathbf{h}$ has chlorine group. By comparing their activity of $\mathrm{ABCB} 1$ pump inhibition, it can be deduced that the methoxy group is the most favorable for activity. However, the activity of compound $\mathbf{f}$ is greater than that of product $\mathbf{g}$. This amelioration of activity for the compound containing a chlorine group can be attributed to the position of the carbon chain (f at position 4 , $\mathbf{g}$ at position 3 ). This suggests that alkylation at the 4position would be better for the MDR-reversing activity. In addition, compounds $\mathbf{a}$ and $\mathbf{e}$ both have a long side chain, but for product $\mathbf{a}$, the chain is carried by a triazole group. Therefore, the presence of heteroatoms on the side chain, in particular nitrogen, improves the MDR-reversing activity of the imidazo[4,5-b]pyridine derivatives. It can be concluded that the novel imidazo[4,5-b]pyridine derivatives presented with potent MDR-reversing activities together with anticancer properties to a varying degree. For additional understanding of the structure-activity relationships (SAR) of these
Table III. Rhodamine 123 accumulation assay in the presence of imidazo[4,5-b]pyridine derivatives against multidrug resistant (MDR) mouse T-lymphoma cells.

\begin{tabular}{lccr}
\hline Compound & $\begin{array}{c}\text { Concentrations } \\
(\mu \mathrm{M})\end{array}$ & $\begin{array}{c}\text { Fluorescence activity } \\
\text { ratio (FAR) }\end{array}$ & $\begin{array}{c}\text { FAR quotient } \\
(\%)\end{array}$ \\
\hline Verapamil & 20 & 11.83 & - \\
a & 2 & 16.96 & 143.35 \\
& 20 & 28.09 & 237.42 \\
b & 2 & 1.42 & 12.01 \\
& 20 & 1.67 & 14.16 \\
c & 2 & 1.74 & 14.69 \\
& 20 & 3.21 & 27.15 \\
d & 2 & 1.73 & 14.60 \\
& 20 & 57.55 & 486.49 \\
e & 2 & 0.91 & 7.72 \\
& 20 & 0.92 & 7.74 \\
f & 2 & 2.02 & 17.11 \\
& 20 & 55.54 & 469.47 \\
g & 2 & 1.52 & 12.85 \\
& 2 & 19.66 & 166.18 \\
h & 20 & 1.26 & 10.66 \\
& 2 & 1.17 & 9.86 \\
i & 20 & 10.59 & 89.50 \\
& & 51.24 & 433.12 \\
DMSO & & 0.78 & 6.57 \\
\hline
\end{tabular}

compounds, the synthesis of additional derivatives and further biological assays are warranted.

\section{Acknowledgements}

This study was supported by the European Union and the State of Hungary, co-financed by the European Social Fund in the framework of TÁMOP 4.2.4. A/2-11-1-2012-0001 'National Excellence Program'. Gabriella Spengler was supported by the János Bolyai Research Scholarship of the Hungarian Academy of Sciences. Márió Gajdács and Gabriella Spengler received funding from the Márton Áron Research Programme (2017/18) financed by the Hungarian Ministry of Foreign Affairs and Trade. Márió Gajdács was supported by the ÚNKP-17-3 New National Excellence Program of the Ministry of Human Capacities. The study was supported by the Szeged Foundation for Cancer Research.

\section{References}

1 Stewart W and Wild P: World Cancer Report. World Health Organization, Geneva, Switzerland, 2014.

2 Baguley BC: Multidrug resistance in cancer. Methods Mol Biol 596: 1-14, 2010.

3 Kathawala RJ, Gupta P, Ashbry CR Jr and Chen ZS: The modulation of $\mathrm{ABC}$ transporter-mediated multidrug resistance in cancer: a review of the past decade. Drug Res Updat 18: 1-17, 2015.

4 Temple C Jr., Rose JD, Comber RN and Rener GA: Synthesis of potential anticancer agents: imidazo[4, 5-c]pyridines and imidazo[4, 5-b]pyridines. J Med Chem 30: 1746-1751, 1987. 
5 Cristalli G, Vittori S, Eleuteri A, Grifantini M, Volpini R, Lupidi G, Capolongo A and Pesenti E: Purine and 1-deazapurine ribonucleosides and deoxyribonucleosides: synthesis and biological activity. J Med Chem 34: 2226-2230, 1991.

6 Hranjec M, Lučić B, Ratkaj I, Pavelić SK, Piantanida I, Pavelić $\mathrm{K}$ and Karminski-Zamola G: Novel imidazo[4, 5-b]pyridine and triaza-benzo[c]fluorene derivatives: Synthesis, antiproliferative activity and DNA binding studies. Eur J Med Chem 46: 2748$2758,2011$.

7 Cristalli G, Vittori S, Eleuteri A, Volpini R, Camaioni E, Lupidi G, Mahmood N, Bevilacqua F and Palu G: Synthesis and biological evaluation of N6-cycloalkyl derivatives of 1-deazaadenine nucleosides: a new class of anti-human immunodeficiency virus agents. J Med Chem 38: 4019-4025, 1995.

8 Cundy DJ, Holan G, Otaegui M and Simpson, GW: 3-[(3'Hydroxymethyl)-4'-hydroxybutyl]imidazo[4, 5-b]pyridines-novel antiviral agents. Bioorg Med Chem Lett 7: 669-674, 1997.

9 Banie H, Sinha A, Thomas RJ, Sircar JC and Richards ML: 2phenylimidazopyridines, a new series of Golgi compounds with potent antiviral activity. J Med Chem 50: 5984-5993, 2007.

10 Temple C Jr.: Antimitotic agents. Synthesis of imidazo[4, 5c]pyridin-6-ylcarbamates and imidazo[4, 5-b]pyridin-5ylcarbamates. J Med Chem 33: 656-661, 1990.

11 Mader M, de Dios A, Shih C, Bonjouklian R, Li T, White W, López UB, Sánchez-Martinez C, del Prado M, Jaramillo C, de Diego E, Martín Cabrejas LM, Dominguez C, Montero C, Shepherd T, Dally R, Toth JE, Chatterjee A, Pleite S, Blanco-Urgoiti J, Barberis M, Lorite MJ, Jambrina E, Nevill CR Jr., Lee PA, Schultz RC, Wolos JA, Li LC, Campbell RM and Anderson BD: Imidazolyl benzimidazoles and imidazo[4,5-b]pyridines as potent p38 $\alpha$ MAP kinase inhibitors with excellent in vivo antiinflammatory properties. Bioorg Med Chem Lett 18: 179-183, 2008.

12 Ge X, Feng Z, Xu T, Wu B, Chen H, Xu F, Fu L, Shan X, Dai Y, Zhang Y and Liang, G: A novel imidazopyridine derivative, X22, attenuates sepsis-induced lung and liver injury by inhibiting the inflammatory response in vitro and in vivo. Drug Des Dev Ther 10: 1947-1959, 2016.

13 Bukowski L and Kaliszan R: Imidazo[4,5-b]pyridine derivatives of potential tuberculostatic activity II: synthesis and bioactivity of designed and some other 2-cyanomethylimidazo[4,5-b]pyridine derivatives. Archiv der Pharmazie 324: 537-542, 1991.

14 Harer SL and Bhatia MS: Design and One-Pot Synthesis of $(1 \mathrm{H}$, 3H)Imidazo[4,5-b]Pyridines: Novel Therapeutic Agents Against M. tuberculosis. Chem Sci Trans 4: 1-16, 2015.

15 Feng DM, Wai JM, Kuduk SD, Ng C, Murphy KL, Ransom RW, Chang RS, MacNeil T, Tang C, Prueksaritanont T, Freidinger RM, Pettibone DJ and Bock MG: 2,3-Diaminopyridine as a platform for designing structurally unique nonpeptide bradykinin B 1 receptor antagonists. Bioorg Med Chem Lett 15: 2385-2388, 2005.

16 Weier RM, Khanna IK, Stealey MA and Julien JA: U.S. Patent No. 5.262.426. Washington, DC: U.S. Patent and Trademark Office, 1993, and Weier RM, Khanna IK, Stealey MA, Julien JA, \& Lentz KT. U.S. Patent No. 5.359.073. Washington, DC: U.S. Patent and Trademark Office, 1994.

17 Kulkarni SS and Newman AH: Discovery of heterobicyclic templates for novel metabotropic glutamate receptor subtype 5 antagonists. Bioorg Med Chem Lett 17: 2987-2991, 2007.

18 Cappelli A, Pericot Mohr GL, Giuliani G, Galeazzi S, Anzini M, Mennuni L, Ferrari F, Makovec F, Kleinrath EM, Lanfer T, Valoti M, Giorgi G and Vomero S: Further studies on imidazo [4, 5-b] pyridine AT1 angiotensin II receptor antagonists. Effects of the transformation of the 4-phenylquinoline backbone into 4phenylisoquinolinone or 1-phenylindene scaffolds. J Med Chem 49: 6451-6464, 2006.

19 McGuinness BF, Cole AG, Dong G, Brescia MR, Shao Y, Henderson I, Rokosz LL, Stauffer TM, Mannava N, Kimble EF, Hicks C White N, Wines PG and Quadros E: Discovery of 2aminoimidazopyridine adenosine A $2 \mathrm{~A}$ receptor antagonists. Bioorg Med Chem Lett 20: 6845-6849, 2010.

20 Sharom FJ, Yu X, Chu JW and Doige CA: Characterization of the ATPase activity of P-glycoprotein from multidrug-resistant Chinese hamster ovary cells. Biochem J 308: 381, 1995.

21 Kale RP, Shaikh MU, Jadhav GR and Gill CH: Eco-friendly and facile synthesis of 2-substituted-1H-imidazo[4, 5-b]pyridine in aqueous medium by air oxidation. Tetrahedron Letters 50: 1780$1782,2009$.

22 Bourichi S, Rodi YK, Misbahi K, Chahdi FO, Akhazzane M and Essassi EM: Etude de la réaction d'alkylation de la 6-bromo-2-(4methoxyphenyl)-3H-imidazo[4,5-b]pyridine. J Mar Chim Heterocycl 14: 69-75, 2016.

23 Cornwell MM, Pastan I and Gottesman MM: Certain calcium channel blockers bind specifically to multidrug-resistant human $\mathrm{KB}$ carcinoma membrane vesicles and inhibit drug binding to $\mathrm{P}-$ glycoprotein. J Biol Chem 262: 2166-2170, 1987.

24 Takács D, Csonka Á, Horváth Á, Windt T, Gajdács M, Riedl Z, Hajós G, Amaral L, Molnár J and Spengler, G: Reversal of ABCB1-related multidrug resistance of colonic adenocarcinoma cells by phenothiazines. Anticancer Res 35: 3245-3251, 2015.

25 Forster S, Thumser AE, Hood SR and Plant N: Characterization of Rhodamine-123 as a tracer dye for use in in vitro drug transport assays. Plos One 7: e33253, 2012.

26 Domínguez-Álvarez E, Gajdács M, Spengler G, Palop JA, Marć MA, Kieć-Kononowicz K, Amaral L, Molnár J, Jacob C, Handzlik $\mathrm{J}$ and Sanmartín, C: Identification of selenocompounds with promising properties to reverse cancer multidrug resistance. Bioorg Med Chem Lett 26: 2821-2824, 2016.

27 Gajdács M, Spengler G, Sanmartín C, Marć MA, Handzlik J and Domínguez-Álvarez E: Selenoesters and selenoanhydrides as novel multidrug resistance reversing agents: A confirmation study in a colon cancer MDR cell line. Bioorg Med Chem Lett 27: 797802,2017

28 Spengler G, Takács D, Horváth Á, Riedl Z, Hajós G, Amaral L and Molnár J: Multidrug resistance reversing activity of newly developed phenothiazines on P-glycoprotein (ABCB1)-related resistance of mouse T-lymphoma cells. Anticancer Res 34: 1737-1741, 2014.

29 Spengler G, Ocsovszki I, Tönki ÁS, Saijo R, Watanabe G, Kawase M and Molnár J: Fluorinated $\beta$-diketo phosphorus ylides are novel inhibitors of the ABCB1 efflux pump of cancer cells. Anticancer Res 35: 5915-5919, 2015.

30 Spengler G, Molnar J, Viveiros M and Amaral L: Thioridazine induces apoptosis of multidrug-resistant mouse lymphoma cells transfected with the human ABCB1 and inhibits the expression of P-glycoprotein. Anticancer Res 31: 4201-4205, 2011.

31 Acton EM, Narayanan VL, Risbood PA, Shoemaker RH, Vistica DT and Boyd MR: Anticancer specificity of some ellipticinium salts against human brain tumors in vitro. J Med Chem 37: 2185$2189,1997$.

Received April 24, 2018

Revised May 24, 2018

Accepted May 29, 2018 